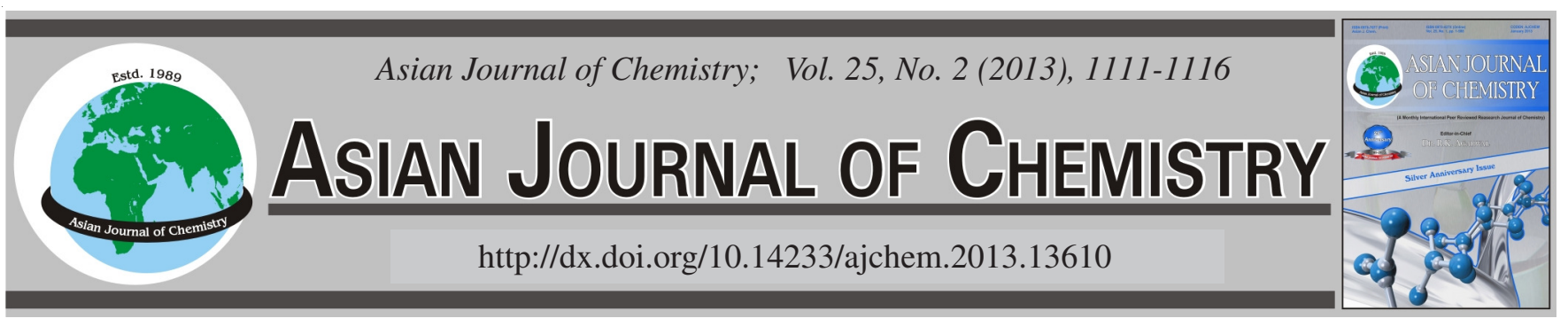

\title{
Kinetic and Equilibrium Modeling of Lead(II) Sorption onto Chemically Pretreated Gossypium hirsutum (Cotton) Leaves Waste Biomass
}

\author{
Muhammad Riaz ${ }^{1,2}$, Raziya Nadeem ${ }^{1, *}$, Muhammad Asif Hanif ${ }^{1}$, Nasir Rasool ${ }^{2}$, Rashid SAeEd $^{3}$, \\ Muhammad Idrees Jilani ${ }^{1}$, Tahira IQbaL ${ }^{1}$ and Muddassar Zafar ${ }^{1}$
}

\author{
${ }^{1}$ Department of Chemistry and Biochemistry, University of Agriculture, Faisalabad-38040, Pakistan \\ ${ }^{2}$ Department of Chemistry, Government College University, Faisalabad-38000, Pakistan \\ ${ }^{3}$ Department of Management Science, COMSATS Institute of Information Technology, Sahiwal Campus, 57000, Pakistan \\ *Corresponding author: Tel: +92 322 8669634; E-mail: raziyaanalyst@gmail.com; raziyaanalyst@yahoo.com
}

(Received: 17 February 2012;

Accepted: 31 August 2012)

AJC-12055

\begin{abstract}
Equilibrium and kinetic aspect of lead(II) biosorption onto chemically pretreated G. hirsutum (cotton) leaves waste biomass was investigated in the present study. The lead(II) sorption was found dependent on solution $\mathrm{pH}$, initial lead(II) concentration, temperature and contact time. The chemical pretreatment of biomass resulted in significant enhancement and reduction in sorption capacity depending on the nature of pretreatment. Results revealed that chemical modifications of $G$. hirsutum (cotton) leaves waste biomass with alkali, inorganic salts, organic salts and organic solvents enhanced the adsorption capacity, while acidic pretreatments caused reduction in adsorption capacity. The sorption data was fitted well to Langmuir isotherm and kinetic data to pseudo second order model, due to higher value of correlation coefficient $\left(\mathrm{R}^{2}\right)$. The effect of contact time showed that sorption of lead(II) occurred rapidly within first $0.5 \mathrm{~h}$ followed by slow adsorption till equilibrium. Present research work illustrated an effective and economical biosorbent for the removal of toxic heavy metals from aqueous solutions.

Key Words: Biosorption, Lead(II), Chemically, Pretreated, G. hirsutum.
\end{abstract}

\section{INTRODUCTION}

The release of heavy metals into the water has happened a matter of concern in the last many years. The heavy metals are released into the water greatly as a result of various industrial mechanisms. The pollutants such as mercury, lead, cobalt, chromium, uranium, zinc, selenium, arsenic, cadmium, nickel and copper are toxic. These toxic materials may be obtained during mining, refining of ores, disposal sludge, electroplating or the manufacture of electrical utensils, batteries, paints and pesticides. Major lead(II) pollution is by automobiles and battery manufacturers. The ground water is also contaminated through seepage of industrial effluents, which may have heavy metals $(\mathrm{Pb}, \mathrm{Hg}, \mathrm{Cr}, \mathrm{As}, \mathrm{Ni}$ and $\mathrm{Cd})$ which all are noxious in nature ${ }^{1,2}$.

The absorption of heavy metals occurs in microbial world as well as in plants and these elements may be accumulated as they pass through the food chain, leading to toxicity symptoms cellular problems and consistently death ${ }^{3}$. Aquatic life may be strictly affected by heavy metal in the surroundings. Because of toxicity of heavy metals, these may cause different types of damaging effects as cancer, hypertension, dermatitis, skin and organ diseases ${ }^{4}$.
In the body lead(II) can influence hematological (blood), neuromuscular, gastrointestinal, renal, central nervous and reproductive systems. At lower levels of get in touch with, lead poisoning proceeds to hyperirritability, sluggishness and poor memory. Lead affects the body in these systems by damaging the blood cell structure. In human being body, lead damage the sulfhydryl ( $\mathrm{SH}$ ) groups of enzymes essential for the synthesis of heme, which is the oxygen carrying pigment in the blood. Lead may hamper with other metabolic systems of cells in the body ${ }^{5}$. Lead is a potent neurotoxin metal when exists above $0.05 \mathrm{mg} / \mathrm{L}$ in water ${ }^{6}$. The children are badly affected by lead(II) poisoning and can cause mental and brain damage. One of the sever effect of lead(II) is that it can replace calcium in bone and remains there to form a reservoir ${ }^{7}$.

There are some conventional assays used for the elimination of heavy metals from waste water such as ion exchange, reverse osmosis, chemical precipitation, electrodialysis, phytoremediation and ultrafiltration ${ }^{8}$. But these are very costly. So it was needed to build up a new assay for the elimination of heavy metals from dilute solution which is inexpensive and proficient also. The look for new methods relating the elimination of toxic metals from industrial wastewater has intended for the awareness about the biosorption'. Biosorption can be 
explained as the capacity of plant resources to absorb heavy metals from wastewater by physicochemical pathways ${ }^{10,11}$.

Biosorption is an assay which involves a plant material and a solvent, normally water, having dissolved heavy metals to be sorbed. The process continues up till the balance is established in between the amount of sorbate metal ions and its part left behind in the solution. The biosorption ability of a biosorbent can also be enhanced by different chemical pretreatments. The pretreatments change the cell surface either by removing or masking or exposing metal binding places. However the effect of pretreatments on the biosorption capacity of biosorbents until now is less evaluated. In this view the main purpose of present investigation was to study the effect of pretreatment of G. hirsutum (cotton) leaves waste biomass for the removal of lead(II) from aqueous solutions. The selection of G. hirsutum (cotton) leaves waste biomass as a biosorbent was based on it's easily availability without any cost.

\section{EXPERIMENTAL}

Collection of sample: G. hirsutum (cotton) leaves waste material was used in the present research work was collected randomly from various agriculture fields of district Faisalabad, Pakistan and mixed. The plant material was washed with distilled water for three times to remove dust particles, after this it was dried in open air then in Eeyla vacume oven (VOC$300 \mathrm{SD}$ ) at $50 \pm 1{ }^{\circ} \mathrm{C}$ for 3 days, till constant weight. The dried plant material was ground by using food processor (Moulnex, France) and then sieved through the siever (OCT-DIGITAL 4527-01) to obtain biomass of homogenous $0.250 \mathrm{~mm}$ particle size. This G. hirsutum (cotton) leaves waste biomass was used for the biosorption of lead from aqueous solutions.

All chemicals used in present study were of analytical grade, including sodium hydroxide, $\mathrm{Pb}\left(\mathrm{NO}_{3}\right)_{2}$ ( $\mathrm{BDH}$, England), conc. hydrochloric acid, phosphoric acid, detergent, sodium carbonate, calcium hydroxide, formaldehyde, EDTA, acetone, benzene, sodium choride, calcium chloride, aluminium hydroxide, mercurous chloride, methanol and formic acid (Merck) and lead(II) standard solution $1000 \mathrm{mg} / \mathrm{L}$ (Fluka chemicals) were purchased from analytical measuring systems, Lahore, Pakistan.

Chemical pretreatment of biosorbent: In order to evaluate the efficiency of $G$. hirsutum (cotton) leaves waste were pretreated with different chemicals such as sodium hydroxide, conc. hydrochloric acid, phosphoric acid, detergent, sodium carbonate, calcium hydroxide, formaldehyde, EDTA, acetone, benzene, sodium chloride, calcium chloride, aluminium hydroxide, mercurous chloride, was carried out. For each pretreatment $10 \mathrm{~g}$ of $G$. hirsutum (cotton) leaves waste material was treated with $0.1 \mathrm{M}, 250 \mathrm{~mL}$ solution of each chemical for $24 \mathrm{~h}$ in $500 \mathrm{~mL}$ conical flasks. For methylation $5 \mathrm{~g}$ of raw biomass was mixed with $100 \mathrm{~mL}$ of formaldehyde and 200 $\mathrm{mL}$ of formic acid and the reaction mixture was shaken on rotary shaker for $6 \mathrm{~h}$ at $200 \mathrm{rpm}$. This treatment was probable to result in the methylation of amino group. For esterification $5 \mathrm{~g}$ of the raw biomass was dissolved in $500 \mathrm{~mL}$ of methanol and $5 \mathrm{~mL}$ of conc. $\mathrm{HCl}$ was added in the suspension material. The mixture was shaken on rotary shaker for $6 \mathrm{~h}$ at $200 \mathrm{rpm}$.
This treatment caused the esterification of the carboxylic group present in the plant material ${ }^{12}$.

After each pretreatment all sample were filtered using filter paper and $\mathrm{pH}$ of samples were made neutral by washing sample with distilled water. The residue was collected and dried in open environment then in Eeyla vacume oven (VOC-300 SD) at $50{ }^{\circ} \mathrm{C}$ for three days till constant weight. Now biomass was grinded again and sieved to get particle size $0.250 \mathrm{~mm}$ was taken. All samples were stored in plastic bottles at room temperature till further analysis.

Preparation of lead solutions: To prepare stock lead(II) solution $(1000 \mathrm{mg} / \mathrm{L}), 1.598 \mathrm{~g}$ of $\mathrm{Pb}\left(\mathrm{NO}_{3}\right)_{2}$ was dissolved in $100 \mathrm{~mL}$ of distilled water and volume was made $1000 \mathrm{~mL}$ using distilled water. The stock solution was stored in plastic bottles. A series of intermediate solutions having lead(II) concentration $25-800 \mathrm{mg} / \mathrm{L}$ lead(II) solutions were prepared by diluting the stock solution with appropriate amount of distilled water.

Batch biosorption studies: To evaluate the effect of different parameters such as $\mathrm{pH} 2$ to 5 ( $\mathrm{pH}$ was adjusted by $0.1 \mathrm{M}$ $\mathrm{NaOH}$ and $0.1 \mathrm{M} \mathrm{HCl}$ ), the various metal concentration (25, $50,100,200,400,600,800$ and $1000 \mathrm{mg} / \mathrm{L}$ ), temperature 30$50{ }^{\circ} \mathrm{C}$ and kinetics were studied in batches. In all experiments $100 \mathrm{~mL}$ solution of lead(II) was taken in $250 \mathrm{~mL}$ conical flasks and $0.05 \mathrm{~g}$ pretreated biosorbent was added to each flask, along with blank for each experiment without adding biosorbent. Flasks were sealed with aluminium foil and agitated in orbital shaking incubator at $130 \mathrm{rpm}$ at $30{ }^{\circ} \mathrm{C}$ for $24 \mathrm{~h}$. After the completion of each experiment all sample were filtered using Whatman filter paper No. 42 and stored in plastic bottles.

Lead(II) analysis: Lead(II) concentration analysis before and after biosorption was carried out by atomic absorption spectrophotometer equipped with lead hollow cathode lamp using an air-acetlyne flame. The hollow cathode lamp was run at $15 \mathrm{~mA}$ current, $217 \mathrm{~nm}$ wavelength and $0.7 \mathrm{~nm}$ slit width.

Adsorption capacity: Adsorption capacity was calculated by eqn. 1 .

$$
\mathrm{q}=\mathrm{V}\left(\mathrm{C}_{\mathrm{i}}-\mathrm{C}_{\mathrm{e}}\right) / \mathrm{W}
$$

where $\mathrm{q}$ is the adsorption capacity $(\mathrm{mg} / \mathrm{g}), \mathrm{C}_{\mathrm{i}}$ is initial lead(II) concentration (mg/L), $\mathrm{C}_{\mathrm{e}}$ is equilibrium lead(II) concentration $(\mathrm{mg} / \mathrm{L}), \mathrm{V}(\mathrm{L})$ is volume of solution and $\mathrm{W}(\mathrm{g})$ is amount of biosorbent.

Statistical analysis: All data represented the average of triplicate experiments. All statistical analysis was carried out by using Costat software.

\section{RESULTS AND DISCUSSION}

In present study, the effect of chemically pretreated $G$. hirsutum (cotton) leaves waste biomass has been investigated. It has been reported that the biosorption of heavy metals depends upon different parameters such as $\mathrm{pH}$, initial metal concentration, temperature and kinetics ${ }^{13}$.

pH profile studies for lead(II) biosorption: $\mathrm{pH}$ is the most important parameter on biosorption process, because it affects the chemistry of the heavy metals in aqueous solutions, the activity of the functional groups in the biomass and the competition of metallic ions ${ }^{14}$. The site dissociation and solution chemistry of the heavy metals such as complexation 
by organic and/or inorganic ligands, hydrolysis, precipitation and redox reactions are strongly influenced by $\mathrm{pH}$, on also powerfully affects the biosorption of the heavy metals ${ }^{15}$. A significant increase in lead removal per weight of plant material was obtained as the $\mathrm{pH}$ increased from 2 to 5 (Fig. 1(a-c). The maximum biosorption ability of $\mathrm{NaOH}$ pretreated $\left(\mathrm{q}_{\mathrm{e}}=178\right.$. $25 \mathrm{mg} / \mathrm{g}$ ) G. hirsutum (cotton) leaves waste biomass was observed at $\mathrm{pH} 5$; beyond which precipitation occurred. Similar results have been reported by other researchers ${ }^{1,6,16}$. At low $\mathrm{pH}$ the overall charge on the biomass remains positive, which prevents the binding of positively charged metal ions. These results may suggest that the functional groups on the plant material cell walls and their ionic states at these $\mathrm{pH}$ values determine the degree of biosorption. The other significant grounds is that at lower $\mathrm{pH}$ the cell wall ligands would be strongly linked with the $\mathrm{H}_{3} \mathrm{O}^{+}$ions that limit access to ligands by metallic ions as a consequence of repulsive forces. This repulsion force is greater at low $\mathrm{pH}$ value. By increasing the $\mathrm{pH}$, additional ligands (carrying negative charges) would be exposed with the following attraction of the positively charged metal ions ${ }^{1}$. These results showed that $\mathrm{pH}$ has a major effect on lead(II) binding to G. hirsutum (cotton) leaves waste biomass.

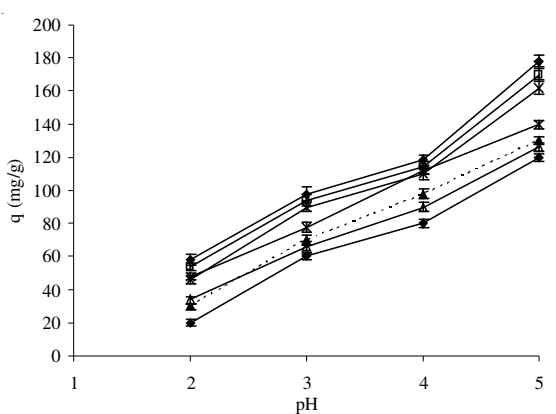

(a)

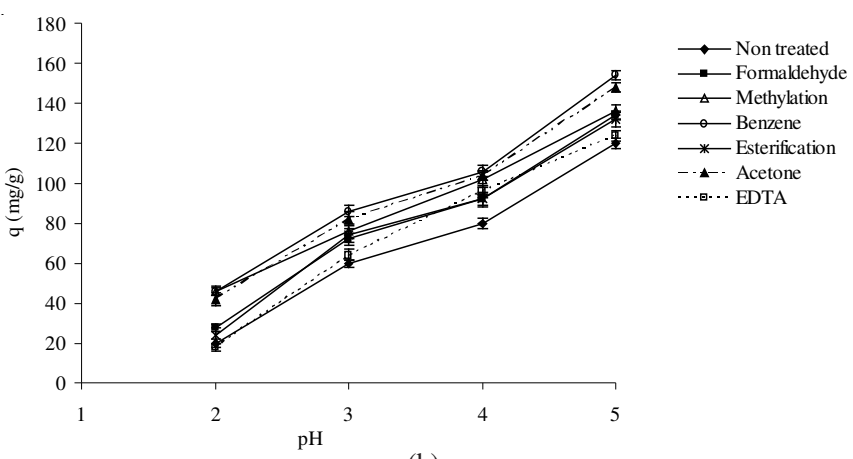

(b)

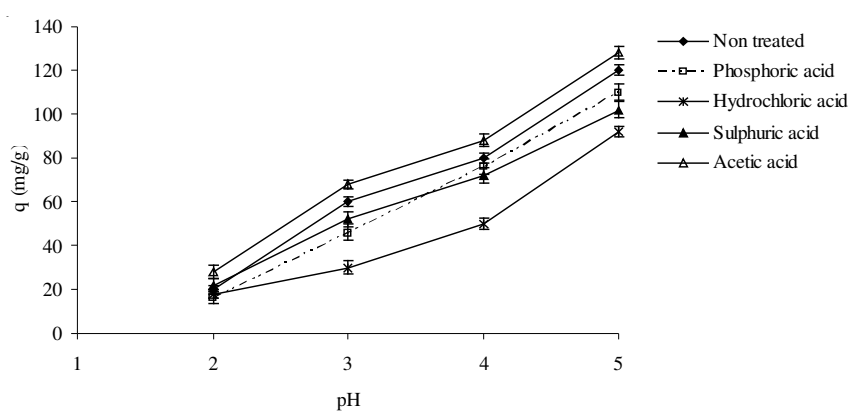

(c)

Fig. 1. Effect of $\mathrm{pH}$ on $\mathrm{Pb}(\mathrm{II})$ biosorption by basically and salts treated (a), organic solvents treated (b) and acid treatment (c) G. hirsutum (cotton) leaves waste biomass
Effect of pretreatments: The chemical pretreatments of plant material may enhance or reduce the adsorption ability of biomass ${ }^{17}$. The chemical pretreatments may alter the cell surface either by removing or masking the functional groups or exposing more metal binding sites in the biomass. The uptake capacity 'q' was enhanced in case of alkali, organic solvents and EDTA. NaOH treated G. hirsutum (cotton) leaves waste biomass showed maximum incease in biosorption of lead(II) (Fig. 2). The pretreatment by $\mathrm{NaOH}$ may rupture the biomass cells which could loose polymers such as polysaccharides that have a greater resemblance towards certain metal ions ${ }^{18}$.

The adsorption capacity 'q' (mg/g) of non treated and chemically pretreated G. hirsutum (cotton) leaves waste biomass. was in following order: sodium hydroxide (178.25 $\pm 1.06)>$ sodium carbonate $(170.36 \pm 1.22)>$ calcium hydroxide $(162.71 \pm 1.34)>$ formaldehyde $(154.14 \pm 1.75)>$ EDTA $(148.15 \pm 1.36)>$ methylation $(140.24 \pm 1.29)>$ acetone $(136.12 \pm 1.03)>$ benzene $(134.85 \pm 1.01)>$ esterification $(132.25 \pm 0.97)>$ sodium choride $(130.14 \pm 1.05)>$ calcium chloride $(128.36 \pm 1.48)>$ aluminium hydroxide $(126.25 \pm 1.19)>$ mercurous chloride $(124.25 \pm 1.32)>$ non treated $(120.14 \pm 1.35)>$ phosphoric acid $(116.52 \pm 0.94)>$ hydrochloric acid $(110.26 \pm 1.5$. The pretreatments of maximum adsorption capacity such as sodium hydroxide, acetone, sodium carbonate, EDTA, formaldehyde and methylation were optimized for further study.

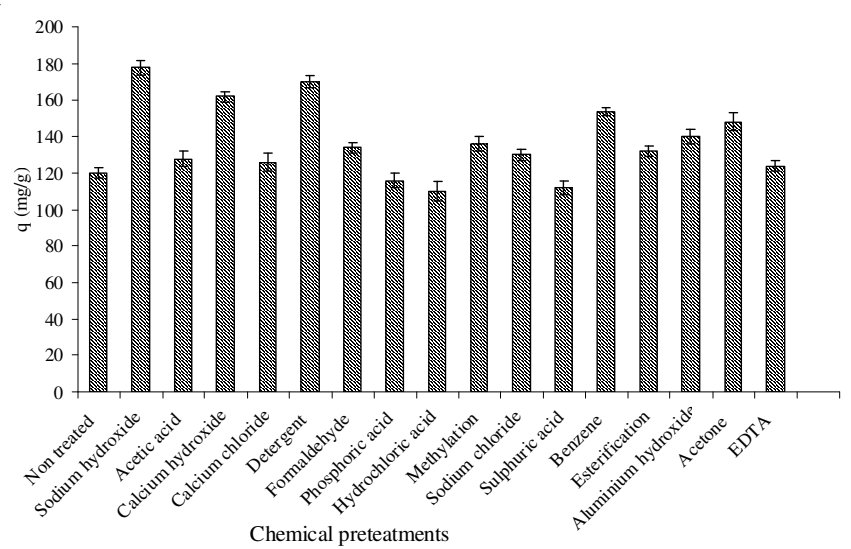

Fig. 2. Effect of different chemical pretreatments for $\mathrm{Pb}(\mathrm{II})$ biosorption by G. hirsutum (cotton) leaves waste biomass

Effect of lead(II) concentration: Results revealed that the adsorption capacity (q) increased with the increase in lead(II) concentration by fixed biosorbent dose $0.05 \mathrm{~g}$ (Fig. 3a). This type of biosorption feature showed that surface saturation was dependent on the lead(II) concentrations. On increasing the metal concentration, percentage of metal uptake decreases due to diminishing loading capacity of biological material. In order to understand the biosorption mechanism the Freundlich and Langmuir isotherms ${ }^{19,20}$, were used to evaluate the equilibrium relationship for different lead (II) concentrations (Figs. 3 (b-c), respectively). The Langmuir equation assumes that biosorption is limited to monolayer process. The linearized form of this equation can be represented as:

$$
\mathrm{C}_{\mathrm{e}} / \mathrm{q}_{\mathrm{e}}=1 / \mathrm{X}_{\mathrm{m}} \cdot \mathrm{K}_{\mathrm{L}}+\mathrm{C}_{\mathrm{e}} / \mathrm{X}_{\mathrm{m}}
$$


where $\mathrm{q}_{\mathrm{e}}(\mathrm{mg} / \mathrm{g})$ is the equilibrium adsorption capacity, $\mathrm{C}_{\mathrm{e}}(\mathrm{mg} /$ $\mathrm{L})$ is equilibrium concentration of metal ion solution, $X_{m}\left(q_{\max }\right)$ is the maximum amount of metal which can be uptaken by the biosorbent. Maximum adsorption capacity and $\mathrm{K}_{\mathrm{L}}$ is the Langmuir constant.

The Freundlich equation is another model which has been usually used to explain adsorption isotherm. Its linearized form is represented by the following equation.

$$
\log \mathrm{q}_{\mathrm{e}}=\log \mathrm{K}_{\mathrm{F}}+1 / \mathrm{n} \log \mathrm{C}_{\mathrm{e}}
$$

where $\mathrm{q}_{\mathrm{e}}(\mathrm{mg} / \mathrm{g})$ is the amount adsorbed per unit mass of adsorbent. $\mathrm{C}_{\mathrm{e}}(\mathrm{mg} / \mathrm{L})$ is quilibrium concentration lead(II) ion concentration. $\mathrm{K}_{\mathrm{F}}$ and $1 / \mathrm{n}$ are constants obtained from the regression equation called intercept and slope respectively. The Maximum value of $\mathrm{R}^{2}$ recommended that the Langmuir isotherm describes the sorption process well as compared to model of Freundlich (Table-1). The linearized plots of Freundlich and Langmuir are presented in Figs. 3(b-c) respectively.

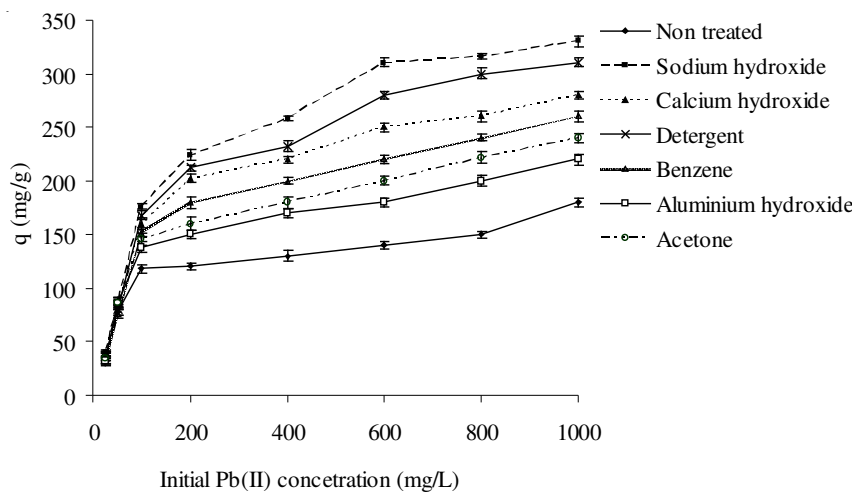

Fig. 3(a). Effect of different initial lead(II) ion concentrations for biosorption by chemically pretreated $G$. hirsutum (cotton) leaves waste biomass

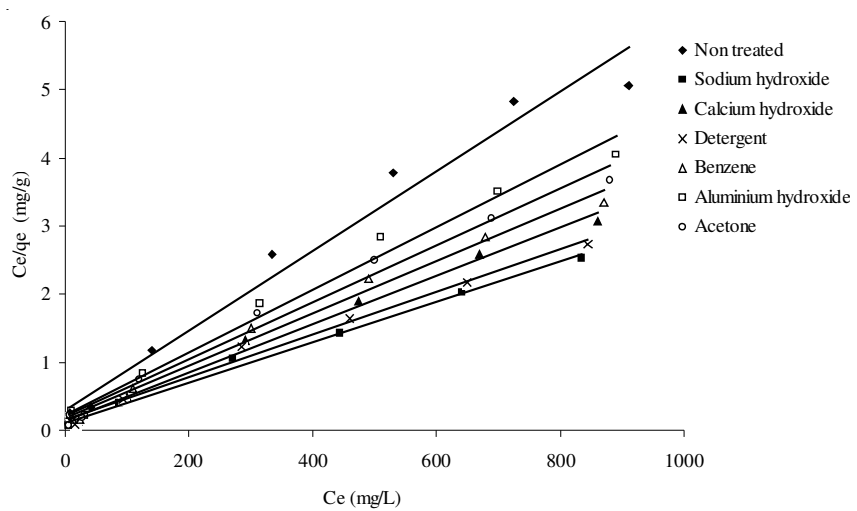

Fig. 3(b). Langmuir isotherm for lead(II) biosorption by chemically pretreated G. hirsutum (cotton) leaves waste biomass

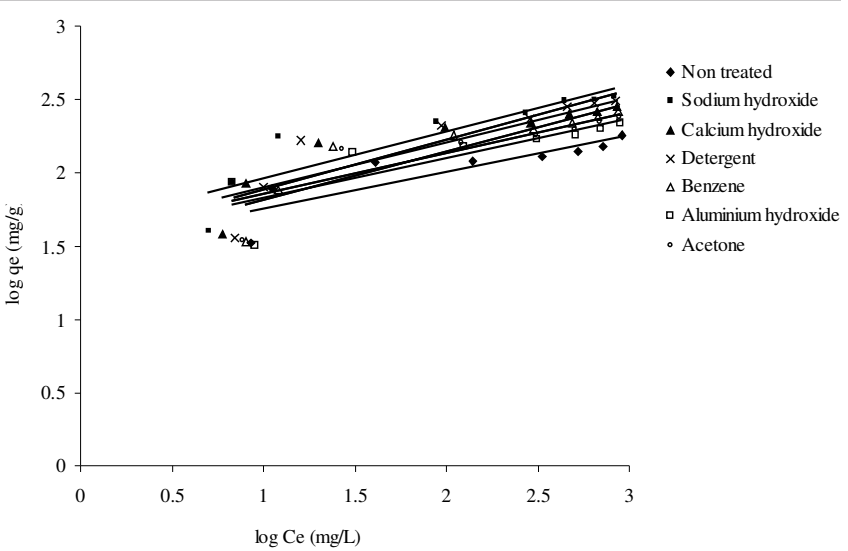

Fig. 3(c). Freundlich isotherm for lead(II) biosorption by chemically pretreated $G$. hirsutum (cotton) leaves waste biomass

Effect of temperature: Biosorption was studied as a function of temperature, because of the regional and seasonal variation in temperature. The temperature range evaluated was between 30 to $50 \pm 1{ }^{\circ} \mathrm{C}$. As temperature is a vital parameter in biosorption reactions. The effect of temperature on the uptake of lead(II) in aqueous solution by chemically pretreated G. hirsutum (cotton) leaves waste biomass was evaluated (Fig. 4). It is evident that adsorption of lead(II) by the G. hirsutum (cotton) leaves waste biomass increased with increase in temperature from 30 to $35^{\circ} \mathrm{C}$. However, subsequent decrease in adsorption capacity was observed when temperature was increased beyond $35^{\circ} \mathrm{C}$ upto $50^{\circ} \mathrm{C}$. The results from temperature studies also indicate that the process is adsorption because the amount of adsorbate on adsorbent is expected to be decrease with incease in temperature. Studies also showed that the process is adsorption because the amount of adsorbent is expected to decrease with temperature for biosorption process. The decrease in adsorption capacity when temperature increased beyond $35 \pm 1{ }^{\circ} \mathrm{C}$, may be due to the attractive forces between biomass surface and the metal ions, which weakened and the biosorption decreases which results in the decrease in the thickness of the boundary layer, due to the increased tendency of the metal ion to escape from the biomass surface to the solution. The ultimately result is a diminish in biosorption as temperature raised ${ }^{21}$.

Effect of contact time: The experiments were conducted to find out the time necessary to establish equilibrium by chemically pretreated G. hirsutum (cotton) leaves waste biomass to bind the lead(II) ions. The lead(II) ion uptake was rapid within first $0.5 \mathrm{~h}$ followed by slow sorption till equilibrium reached (Fig. 5(a)). From this type of sorption behaviour

TABLE-1

COMPARISON BETWEEN LANGMUIR AND FREUNDLICH ISOTHERM CONSTANTS FOR LEAD(II) BIOSORPTION BY CHEMICALLY PRETREATED G. hirsutum (COTTON) LEAVES WASTE BIOMASS

\begin{tabular}{|c|c|c|c|c|c|c|c|c|}
\hline \multirow{2}{*}{$\begin{array}{l}\text { Pretreatments of } G \text {. hirsutum } \\
\text { (cotton) leaves waste biomass }\end{array}$} & \multirow{2}{*}{$\begin{array}{c}\text { Experimental } \\
\mathrm{q}_{\max }(\mathrm{mg} / \mathrm{g})\end{array}$} & \multicolumn{3}{|c|}{ Langmuir isotherm constants } & \multicolumn{4}{|c|}{ Freundlich isotherm constants } \\
\hline & & $\mathrm{X}_{\mathrm{m}}(\mathrm{mg} / \mathrm{g})$ & $\mathrm{K}_{\mathrm{L}}(\mathrm{L} / \mathrm{mg})$ & $\mathrm{R}^{2}$ & $\mathrm{q}_{\mathrm{e}}(\mathrm{mg} / \mathrm{g})$ & $\mathrm{K}_{\mathrm{F}}(\mathrm{mg} / \mathrm{g})$ & $1 / \mathrm{n}$ & $\mathrm{R}^{2}$ \\
\hline Non treated & 180.12 & 169.49 & 0.0202 & 0.964 & 165.41 & 32.46 & 0.2476 & 0.912 \\
\hline Sodium hydroxide & 330.41 & 333.33 & 0.0279 & 0.993 & 252.30 & 44.61 & 0.3163 & 0.935 \\
\hline Detergent & 310.45 & 322.58 & 0.0205 & 0.981 & 197.67 & 36.14 & 0.2701 & 0.883 \\
\hline Calcium hydroxide & 280.61 & 277.77 & 0.0267 & 0.976 & 242.68 & 38.99 & 0.3078 & 0.864 \\
\hline Benzene & 260.17 & 263.15 & 0.0199 & 0.942 & 256.58 & 30.66 & 0.3302 & 0.893 \\
\hline Aluminium hydroxide & 219.43 & 217.39 & 0.0210 & 0.983 & 209.90 & 36.14 & 0.2701 & 0.914 \\
\hline Acetone & 240.37 & 238.09 & 0.0215 & 0.961 & 212.42 & 37.63 & 0.2791 & 0.921 \\
\hline
\end{tabular}




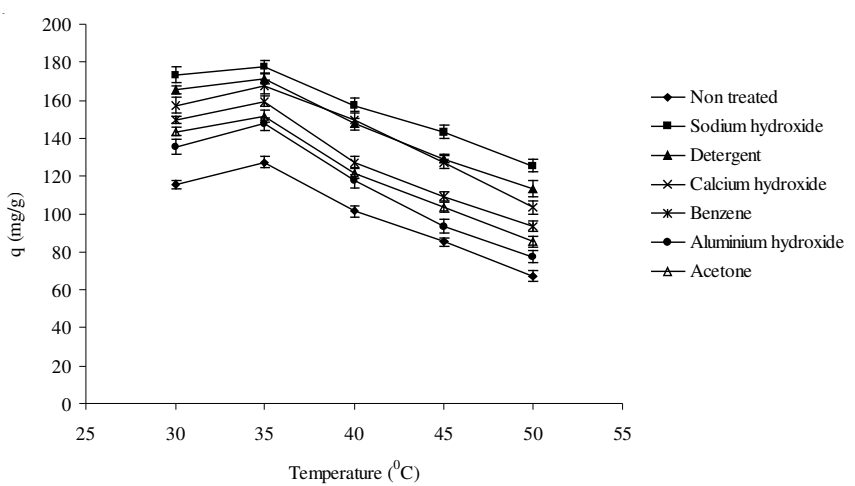

Fig. 4. Effect of temperature for $\mathrm{Pb}$ (II) biosorption by chemically pretreated G. hirsutum (cotton) leaves waste biomass

of chemically pretreated $G$. hirsutum (cotton) leaves waste biomass, it may be concluded that lead(II) ions uptake by $G$. hirsutum (cotton) leaves waste biomass followed a two step mechanism where the metal ions were chemically adsorbed onto the surface of the biosorbent before being absorbed into the inner adsorption sites of the biomass ${ }^{22}$. The first step known as a passive surface transport, took place quite rapidly i.e. within $0.5 \mathrm{~h}$. While the second step is passive diffusion, which may take greater time to reach equilibrium ${ }^{23-26}$. The fast metal uptake (within first $0.5 \mathrm{~h}$ ) observed for chemically pretreated G. hirsutum (cotton) leaves waste biomass is of particular importance to process design and operation in practical uses to treat industrial waste water. The mechanism of biosorption and potential rate controlling steps, such as mass transport and chemical reaction procedures, must be investigated to properly understand adsorption kinetics.

The pseudo first order Lagergren and pseudo second order approach ${ }^{27,28}$. The first order Lagergren equation (eqn. 5) (Fig. 5b)

$$
\log \left(\mathrm{q}_{\mathrm{e}}-\mathrm{q}\right)=\log \mathrm{q}_{\mathrm{e}}-\left(\mathrm{k}_{1, \text { ads }} \mathrm{t}\right) / 2.303
$$

The pseudo second order equation (eqn. 6) (Fig. 5(c)).

$$
\mathrm{t} / \mathrm{q}=1 / \mathrm{k}_{2, \text { ads }} \mathrm{q}_{\mathrm{e}}^{2}+\mathrm{t} / \mathrm{q}_{\mathrm{t}}
$$

where $\mathrm{q}_{\mathrm{e}}$ is the mass of metal adsorbed at equilibrium $(\mathrm{mg} / \mathrm{g})$, $\mathrm{q}_{\mathrm{t}}$ the mass of metal at $\mathrm{t}(\mathrm{min}), \mathrm{k}_{1 \text {, ads }}$ the first order reaction rate constant of adsorption (per min), $\mathrm{k}_{2 \text {, ads }}$ the pseudo second order rate constant of adsorption ( $\mathrm{mg} / \mathrm{g} \mathrm{min}$ ).

A comparison between Lagergren pseudo-first-order and pseudo-second-order kinetic models are explained in Table-2. The second-order rate model has received considerable attention as a tool for quantitatively predicting the uptake of metals from aqueous solutions. In addition to high value of coefficient of determination $\left(\mathrm{R}^{2}\right)$, a close agreement between experimental

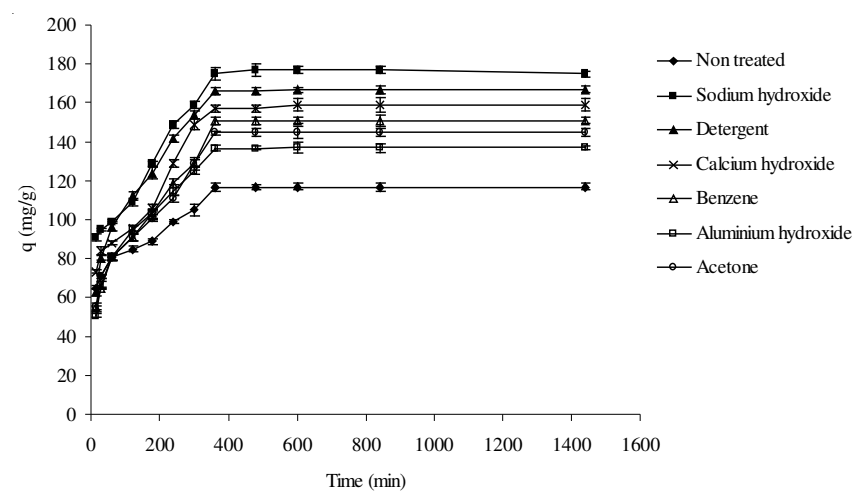

Fig. 5(a). Effect of contact time for lead(II) biosorption by chemically pretreated G. hirsutum (cotton) leaves waste biomass

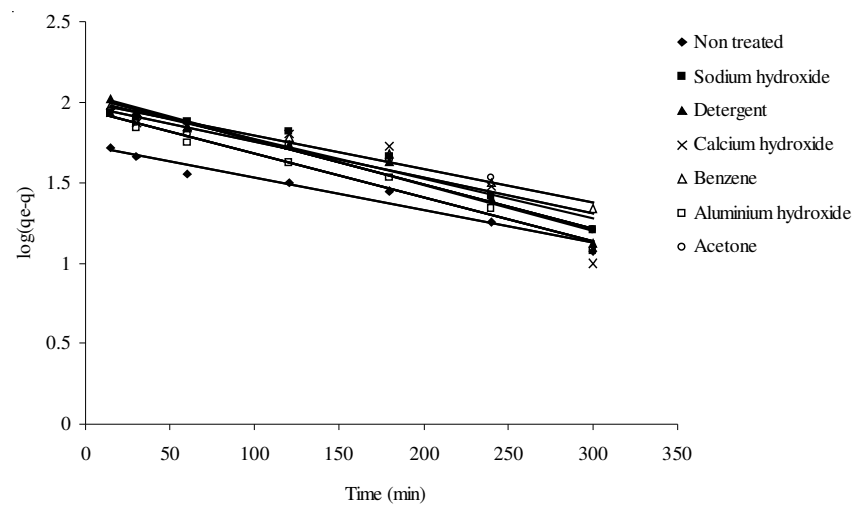

Fig. 5(b). Pseudo first order kinetic model for $\mathrm{Pb}(\mathrm{II})$ biosorption by chemically pretreated $G$. hirsutum (cotton) leaves waste biomass

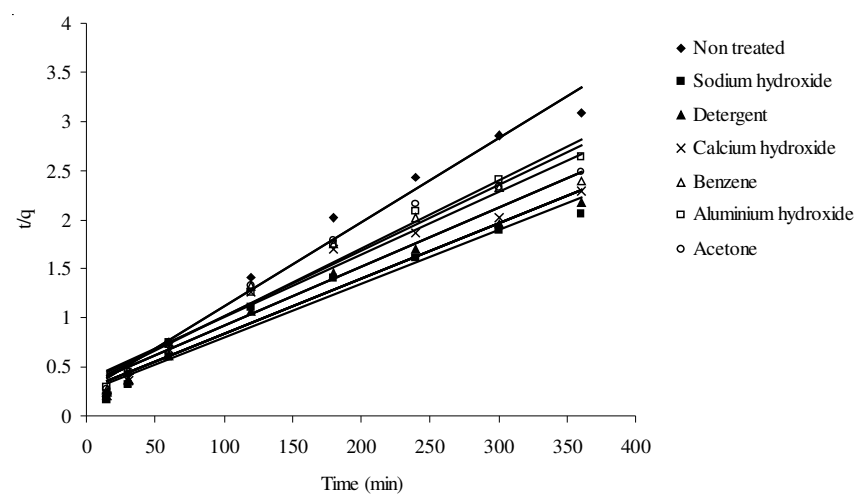

Fig. 5(c). Pseudo second order kinetic model for $\mathrm{Pb}(\mathrm{II})$ biosorption by chemically pretreated $G$. hirsutum (cotton) leaves waste biomass

and estimated $\mathrm{q}_{\mathrm{e}}$ values suggests that sorption process followed second order mechanism. In this model, the rate-limiting step is a biosorption mechanism involving chemisorption, where

TABLE-2

COMPARISON BETWEEN ADSORPTION PARAMETERS OF LAGERGREN PSEUDO-FIRST ORDER

\begin{tabular}{|c|c|c|c|c|c|c|c|}
\hline \multirow{2}{*}{$\begin{array}{l}\text { Pretreatments of } G \text {. hirsutum } \\
\text { (cotton) leaves waste biomass }\end{array}$} & \multirow{2}{*}{$\begin{array}{l}\text { Experimental } \\
\mathrm{q}_{\max }(\mathrm{mg} / \mathrm{g})\end{array}$} & \multicolumn{3}{|c|}{ Pseudo first order constants } & \multicolumn{3}{|c|}{ Pseudo second order constants } \\
\hline & & $\mathrm{q}_{\mathrm{e}}(\mathrm{mg} / \mathrm{g})$ & $\mathrm{k}_{1}\left(\min ^{-1}\right)$ & $\mathrm{R}^{2}$ & $\mathrm{q}_{\mathrm{e}}(\mathrm{mg} / \mathrm{g})$ & $\mathrm{k}_{2}(\mathrm{~g} / \mathrm{mg} \min )$ & $\mathrm{R}^{2}$ \\
\hline Non treated & 116.22 & 54.13 & $5.06 \times 10^{-3}$ & 0.934 & 116.27 & $2.91 \times 10^{-4}$ & 0.951 \\
\hline Sodium hydroxide & 174.45 & 104.97 & $5.75 \times 10^{-3}$ & 0.910 & 181.81 & $3.13 \times 10^{-5}$ & 0.982 \\
\hline Detergent & 166.78 & 114.10 & $6.67 \times 10^{-3}$ & 0.942 & 178.57 & $3.20 \times 10^{-5}$ & 0.970 \\
\hline Calcium hydroxide & 158.95 & 108.99 & $6.44 \times 10^{-3}$ & 0.845 & 166.66 & $3.81 \times 10-^{5}$ & 0.946 \\
\hline Benzene & 150.65 & 102.02 & $4.83 \times 10^{-3}$ & 0.827 & 156.25 & $4.29 \times 10^{-5}$ & 0.954 \\
\hline Aluminium hydroxide & 136.73 & 89.37 & $6.21 \times 10^{-3}$ & 0.924 & 144.92 & $4.85 \times 10^{-5}$ & 0.964 \\
\hline Acetone & 144.48 & 94.82 & $5.06 \times 10^{-3}$ & 0.941 & 149.25 & $4.70 \times 10^{-5}$ & 0.972 \\
\hline
\end{tabular}
AND PSEUDO SECOND ORDER KINETIC MODELS FOR Pb(II) BIOSORPTION 
metal removal from solution is due to purely physico-chemical interactions between biomass and metal solution ${ }^{29,30}$.

\section{Conclusion}

In the present study the effect of various chemical pretreatments was evaluated. Results showed that the $\mathrm{pH}$ of solution, contact time and temperature effect the adsorption capacity of biosorbent. From the results of sorption isotherm it is evaluted that Langmuir type suggesting the monolayer sorption character. The maximum biosorption of lead(II) ions quickly reached within first $0.5 \mathrm{~h}$ and then the equilibrium was reached. This work explained that the G. hirsutum (cotton) leaves waste plant material can effectively be employed as natural biopolymer for the uptake of lead(II) from aqueous solutions.

\section{REFERENCES}

1. M.A. Hanif, R. Nadeem, H.N. Bhatti, N.R. Ahmad and T.M. Ansari, J. Hazard. Mater., 139, 345 (2007a).

2. M. Khan, J.M. Arias and S. Sing, Process Biochem., 36, 175 (1999).

3. A. Taylor, Environ. Rural Affairs, 12, 973 (2003).

4. S.H. Mackenzie, Environ. Sci. Technol., 30, 261 (1996).

5. C.D. Klaassen and J.B. Watkins III, Casarett \& Doull's Essentials of Toxicology, pp. 20-25 (2003).

6. R. Nadeem, M.A. Hanif, F. Shaheen, S. Perveen, M.N. Zafar and T. Iqbal, J. Hazard. Mater. 168, 1622 (2007).

7. B. Volesky and Z.R. Holan, Biotechnol. Prog., 11, 235 (1995).

8. B. Shah, A. Shah and R.R. Singh, Int. J. Environ. Sci. Tech., 6, 77 (2009).

9. N.T. Abdel-Ghani, A.K. Hegazy and G.A.E. Chaghaby, Int. J. Environ. Sci. Tech., 6, 243 (2009).
10. Y. Sag, B. Tatatr and T. Kutsa, Bioresour. Technol., 87, 27 (2003).

11. P.X. Sheng, Y.P. Ting, J.P. Chen and L. Hong, J. Colloid Interf. Sci., 275, 131 (2004).

12. A. Kapoor and T. Viraraghavan, Bioresour. Technol., 61, 221 (1997).

13. M.N. Zafar, R. Nadeem and M.A. Hanif, J. Hazard. Mater., 143, 478 (2007).

14. M. Galun, Water Air Soil Pollut., 33, 359 (1987).

15. A. Ozer and D. Ozer, J. Hazard. Mater., 100, 219 (2003).

16. H.N. Bhatti, B. Mumtaz, M.A. Hanif and R. Nadeem, Process Biochem., 42, 547 (2007).

17. G. Yan and T. Viraraghavan, Water SA, 26, 119 (2000).

18. M.W. Mittleman and G.G. Geesey, Appl. Environ. Microbiol., 49, 846 (1985).

19. S.H. Moon, C.S. Park, Y.J. Kim and Y.I. Park, Process Biochem., 41, 312 (2006).

20. M.J. Horsfall and A.I. Spiff, Afr. J. Biotechnol., 4, 191 (2005).

21. M.H. Jnr and A.I. Spiff, J. Biotechnol., 8, 162 (2005).

22. R. Nadeem, M.A. Hanif, M. Riaz, A.A. Azhar, T. Iqbal and T.M. Ansari, Afr. J. Biotechnol., 9, 9051 (2010).

23. P.R. Pavasant, Apiratikul, V. Sungkhum, P. Suthiparinyanont, S. Wattanachira and T.F. Marhaba, Bioresour. Technol., 97, 2321 (2006).

24. K.C. Sekhar, C.T. Kamala, N.S. Chary and Y. Anjaneyulu, Int. J. Miner. Proc., 68, 37 (2003).

25. K.C. Sekhar, C.T. Kamala, N.S.A. Chary, R.K. Sastry, T.N. Rao and M. Vairamani, J. Hazard. Mater., 108, 111 (2004).

26. M.A. Javed, H.N. Bhatti, M.A. Hanif and R. Nadeem, Sci. Technol., 42, 3641 (2007).

27. Y.S. Ho, D.A.J. Wase and C.F. Foster, Environ. Technol., 17, 71 (1996).

28. M.A. Hanif, R. Nadeem, M.N. Zafar, K. Akthar and H.N. Bhatti, J. Hazard. Mater, 145, 501 (2007b).

29. Z. Aksu, Sep. Purif. Technol., 21, 285 (2001).

30. M.H. Nasir, R. Nadeem, K. Akhtar, M.A. Hanif and A.M. Khaild, J. Hazard. Mater., 168, 1622 (2007). 